Status Report 2016-2019

\title{
Contributions to the Palaeozoic and Mesozoic of the Himalaya
}

\author{
O N BHARGAVA ${ }^{1, *}$, BIRENDRA P SINGH ${ }^{1}$, B PANDEY ${ }^{2}, \mathrm{~J} \mathrm{~A} \mathrm{GANAI}^{3}, \mathrm{G} \mathrm{M} \mathrm{BHAT}^{3}, \mathrm{~S} \mathrm{~K} \mathrm{PRASAD}^{1}$ and \\ R A RASHID 4 \\ ${ }^{1}$ Centre of Advanced Studies in Geology, Panjab University, Chandigarh 160 014, India \\ ${ }^{2}$ Department of Geology, Banaras Hindu University, Varanasi, India \\ ${ }^{3}$ Department of Geology, University of Jammu, Jammu and Kashmir, Srinagar, India \\ ${ }^{4}$ Department of Geology, Aligarh Muslim University, Aligarh, India
}

(Received on 08 August 2019; Accepted on 10 October 2019)

\section{Introduction}

In the Himalaya both the Palaeozoic and the Mesozoic sequences are developed in the Tethyan Himalaya, while in the lesser Himalaya only parts of the Palaeozoic (Cambrian, Ordovician and Permian) and Mesozoic (late Cretaceous) are preserved. The difficult terrain combined with travel restrictions, which required special administrative clearance discouraged geological investigations in the Tethyan area. With improvement in the logistics and removal of restrictions, there is a spurt in geological activity in Spiti. The renewed activity in most instances was restricted to short duration due to limited period of field work available in the high-altitude terrain. For obvious reasons, the hurried investigations with little appreciation of regional picture besides generating new data, in some cases created anomalies.

Hughes et al. (2018) in a review paper suggested Parahio Valley Section as the type section for the Cambrian in India and recommended Parahio Formation as name for the Cambrian sequence of the Tethyan Himalaya. Srikantia and Bhargava (2018) contested the claim of Hughes et al. (2018) and stated that the Parahio section is truncated due to a fault and represents only late part of the Cambrian Series 2, Stage 4 to Wulian Stage, Miaolingian Series, while a complete succession is exposed in the Kunzam La section after which the formation is named. Srikantia and Bhargava (2018) also clarified certain arbitrary nomenclature applied to Cambrian, Ordovician and Silurian sequences in contravention of the Indian
Stratigraphic Code of Nomenclature.

Craig et al. (2018) considered that the Palaeozoic setup of the Zanskar basin is rather similar to that of the Peshawar Basin, which constitutes hydrocarbon reservoirs. The thick argillaceous successions of the Palaeozoic and the Mesozoic successions of the Kashmir, Zanskar, Chamba and Spiti basins are potential hydrocarbon source rock horizons. The Mesozoic successions include thick sequences of organic material rich argillaceous sediments. Some of the shales contain organic matter and could represent viable hydrocarbon source rocks, while some of the limestones, dolomites and sandstones have sufficient reservoir characteristics.

\section{Palaeozoic}

\section{Cambrian}

The Cambrian of the Tethyan Himalaya in Spiti and also in the lesser Himalaya has been intensely studied during 2016-2020 for refinement of the biostratigraphy as well as the sedimentology. These are summarised below.

Parcha and Pandey (2016) described Diplichnites, Dimorphichnus, Monomorphichnus, Palaeophycus, Planolites and Skolithos from the Cambrian Kunzam La Formation, Chandra Tal section (Lahaul valley) and interpreted a shallow marine environment for the deposition.

Singh et al. (2016a) precisely demarcated the 
Hayden level 2 in the Kunzam La Formation, in Spiti; it brackets the local stratigraphic range of Oryctocephalus indicus - a key taxon considered for the Global Stratotype and Point Section (GSSP) for the base of the Wuliaun Stage, Miaolingian Series (or Middle Cambrian) and possibly, the Cambrian Series 2-Wuliaun Stage, Miaolingian Series boundary. The FAD and LAD of $O$. indicus are preserved at 7.74 and $14.61 \mathrm{~m}$ respectively, indicating $6.87 \mathrm{~m}$ stratigraphic range of the taxon along the Parahio valley section (Singh et al., 2016a). The FADs of Pagetia and Kunmingaspis, together at $7.34 \mathrm{~m}$ predate the FAD of $O$. indicus $7.74 \mathrm{~m}$. Pagetia ranges from the Cambrian Series 2 (Stage 4) to the base of the Wuliuan Stage, Miaolingian Series and its occurrence in Spiti is consistent with the global occurrences. The taxon, Eosoptychoparia (Danzhaina) sp. was recorded for the ûrst time from the Indian Himalaya.

Singh et al. (2016b) discovered complete specimens of ellipsocephalinae trilobite Bhargavia prakritika from the Kunzam La Formation, Parahiovalley section, Spiti. It enabled elaboration of its diagnostic characters, which earlier were based only on cranidia and pygidia. B. prakritika now has been recorded at $12.1 \mathrm{~m}$ above the Oryctocephalus indicus Zone (Cambrian Series 3, Stage 5), which becomes the lowest stratigraphic level of this taxon, reported so far. This level is equated with the upper part of the Plagiura Zone of the Great basin. Earlier, the type species of $B$. prakritika were known from Kaotaia prachina Zone (Stage 5) around $233.4 \mathrm{~m}$ above the inferred $O$. indicus level (Peng et al., 2009).

Singh et al. (2017a) for the first time recorded from the Pin Valley (Spiti) the trilobite fauna comprising Oryctocephalus indicus, Pagetia significans, Kunmingaspis pervulgata, and Bhargavia prakritika, which ranges from the top part of the Cambrian Series 2 (Stage 4) to the basal most part of the Wuliuan Stage, Miaolingian Series. On the bases of the trilobite fauna and their stratigraphic levels, the Oryctocephalus Zone (5.4 $\mathrm{m})$, interval 1 of no zonation, and the Bhargavia prakritika Level (Wuliuan, Miaolingian) are recognised. The $O$. indicus Zone is based on the FAD and LAD (local range) of the eponymous species in the Pin Valley section. The occurrence of fossiliferous section immediately below the Cambro-Ordovician contact suggests erosion of nearly $1160 \mathrm{~m}$ of the Cambrian strata (deposited within about 2 My, i.e., 509 to $507 \mathrm{Ma}$ ) prior to the deposition of the Ordovician Thango Formation.

Singh et al. (2017b) described the Cambrian Wuliuan Stage, Miaolingian Series, trilobite fauna comprising Peronopsis sp., Eosoptychoparia cf. spinosa, Gaotanaspis cf. pingzhaiensis and Gaotanaspis cf. transversa immediately above the known Oryctocephalus indicus biozone in the Parahio valley (Spiti). The FAD of Peronopsis and LAD of Gaotanaspis were utilized by these authors to establish a Peronopsis-Gaotanaspis concurrent biozone immediately above the Oryctocephalus indicus biozone. The first records of cf. pingzhaiensis and Peronopsis taijiangensis from the Cambrian of Spiti together with the other faunal elements were correlated with the biozone of the Kaili Formation, South China. The stratigraphic thickness from the base of the $O$. indicus biozone to the top of the Peronopsis-Gaotanaspis concurrent biozone in the Kunzam La Formation and its comparison to the Kaili Formation indicate a possible stratigraphic condensation in the basal part of the Cambrian Series 3 , Stage 5 of the Parahio valley (Spiti).

Singh et al. (2017c) reported the first occurrence of Treptichnus pedum and Treptichnus lublinensis from the Cambrian succession of the Spiti Valley (Tethyan Himalaya) and the Nigali Dhar syncline (Lesser Himalaya) respectively. These authors discussed the morphological variation, palaeoenvironmental and stratigraphic significance of Ichnogenus Treptichnus and reviewed the known occurrences of Phycodes pedum and Treptichnus, synonymous and analogous from the Cambrian of India and Bhutan and concluded that in the Himalaya (including Bhutan) the known occurrences of Treptichnus pedum show a range from Cambrian Series 2, Stage 4 to Furongian (Paibian) part, hence not useful for demarcating the Ediacaran-Cambrian boundary. The late appearance of Treptichnus ichnogenus in the Cambrian of the Himalaya was attributed to higher latitudinal position of India during the Early Cambrian. As a result, possibly, the Treptichnus producing organism, i.e. priapulid worms emerged in the later part of the Cambrian Series 2, Stage 4 in both the regions. 
Chaubey et al. (2018) described sedimentology and trace fossils assemblageofa part of the Kunzam La Formation exposed along the Shian section of the Pin Valley. The trace fossil assemblage comprising? Arborichnus isp., Archaeonassa isp., Diplichnites isp., Hormosiroidea isp., Monomorphichnus lineatus, Bergaueriaaf flangi, Palaeophycus tubularis, Rusophycus isp. and Treptichnus-like fossils, occurring stratigraphically below the Oryctocephalus indicus biozone (Series 3, Stage 5) belongs to the late part of Series 2, Stage 4; this finding supersedes the previous Ediacaran-Cambrian boundary age assignment. Integrated ichnofabric and sedimentological data of these authors suggest a stormdominated, lower to upper shoreface of shallowmarine environment.

Yin et al. (2018) described low-diversity acritarch assemblages, including Alliumella baltica, Bavlinella faveolata, Brocholaminaria nigrita, Brocholaminaria sp., Eliasum sp., Leiosphaeridiaminutissima, Leiosphaeridia spp., Lophosphaeridium sp., Pterospermella solida, Satka colonialica, Siphonophycus sp., and Synsphaeridium sp., including a new species Synsphaeridium parahioense together with filamentous algae and cryptospore-like microfossils from 45 rock samples of the Cambrian Kunzam La Formation around the Oryctocephalus indicus Zone (Cambrian Series 3) at the Kaltarbo locality in the Parahio valley, Spiti. The acritarch assemblages at the basal part of the Cambrian Series 3 in the Kunzam La (Parahio) Formation were dependent on the local marine environment. The new discovery of cryptospore-like microfossils from the Cambrian KunzamLa Formation confirmed the extensive distribution of possible cryptospores in the Cambrian sequences.

Kaur et al. (2019) refined the Cambrian biozonation along a continuous section in the Parahio valley and precisely located trilobite faunas of Haydenaspis parvatya level and the $O$. indicus Biozone, which are stratigraphically separated by 183.4 $\mathrm{m}$, which is $62 \mathrm{~m}$ higher than the level estimated by Peng et al. (2009).

Singh et al. (2019) presented an integrated ichnology, sedimentology and sequence stratigraphy from the Lower Quartzite Member to the Arkosic
Sandstone Member of the Koti Dhaman Formation (Cambrian Series 2, Stage 4), Tal Group, Nigali Dhar Syncline, Lesser Himalaya. The trilobite traces Cruziana salomonis, Cruziana fasciculata, Rusophycus dispar and Rusophycus burjensis of Gondwana affinity were reported along with Arenicolites isp., and Skolithos isp. from the Lower Quartzite Member. This rich and diverse ichnoassemblage, attributed to the Cruziana ichnofacies, is the first record from the Arkosic Sandstone Member. Seven ichnofossil assemblages, i.e., Cruziana-Rusophycus, Planolites-Palaeophycus, Cruziana-problematica, Diplichnites, Cochlichnus anguineus, Bergaueria perata and Psammichnites gigas have been recognized in the Lower Quartzite to Arkosic Sandstone members. Seven sedimentary facies are identified in the Koti Dhaman Formation, which indicate shallowing upward parasequences of a tidal flat complex. Overall, two major events are recognized: i) the break in sedimentation between the Lower Quartzite Member and the overlying Shale Member, probably related to forced-regressive event and ii) the facies shift from the Arkosic Sandstone Member represents an erosive transgressive event; the surface is interpreted as wave ravinement surface, which is also a sequence boundary. Integrated studies indicate that the Lower Quartzite Member was deposited in a shallow subtidal sand sheet complex and tidal flat complex, while the Shale Member was deposited in a mud flat setting of a tidal flat complex and the Arkosic Sandstone Member in a mixed-flat (tidal flat complex) to sand sheet complex front and margin (subtidal sand sheet complex). Overall, the lower to middle part of the Koti Dhaman Formation represents a tide-dominated shallow subtidal-intertidal to mud-flat sub-environments of the tidal flat complex. Palaeogeographic reconstruction of lower Cambrian (516-514Ma) based on the distribution of trilobite traces from the Lesser Himalaya and the BikanerNagaur area of Peninsular India (eastern Gondwana), Egypt, Jordan, Turkey (western Gondwana) and Canada (Avalonia) was also proposed by these authors.

\section{Ordovician}

Sinha and Verniers (2016) recorded chitinozoans Belonechitina capitata from the Shiala Formation of Tethyan Kali Valley, Uttrakhand. The authors have suggested that $B$. capitata had a wide latitudinal range 
extending from northern Gondwana, over Avalonia to Baltica, and is a useful guide fossilof the middle to late Ordovician.

Pandey and Parcha (2018) added to the existing record of Ordovician algae in the Himalaya by reporting calcareous algae Dasyporella silurica, Moniliporella multipora and Vermiporella fragilis from the Middle Ordovician (Dapingian to Darriwilian) Thango Formation exposed in the Pin Valley of the Spiti. This algal assemblage indicates shallow marine, warm, well-oxygenated and relatively high-energy environment of deposition. These calcareous algae also known from the Tarim Basin, Kazakhstan, Baltica, North America, Scotland and India indicate that all these terrains were located along the $0-30^{\circ}$ latitudinal belt during the Ordovician period, with a possible link between the Tethyan Himalaya and the Tarim basin.

Chaubey et al. (2019) described warm-water Dasycladaceae algae Mastopora and Cyclocrinites from the Takche Formation (Upper Ordovician-lower Silurian), Parahio Valley, Spiti. The abundance of cyclocrinitid remains indicates location of the Spiti at about $30^{\circ}$ South palaeolatitude during the Late Ordovician and early Silurian. They attributed the extinction of cyclocrinitids at the end of Ordovician period is related to cooling and glaciations.

Cryptostome bryozoan Ptilotrypa bapjaii reported from the lower part of the Yong Limestone, Tethyan Kumaun Himalaya indicates an Upper Ordovician age. The Ordovician-Silurian boundary thus may lie in the upper part of the Yong Limestone or in the overlying Variegated Formation (Swami et al. 2019).

Rashid and Ganai (2018) documented petrography and sedimentology of the siliciclastc rocks of the Thango Formation, Spiti, which suggest three major depositional environments, viz., fluvial, transitional and marine representing transgressive and regressive phases. Geochemical and petrographic studies suggest passive margin tectonic setting for these siliciclastic rocks. Petrographic and geochemical characteristics coupled with some signiûcant immobile elemental ratios and REE patterns and strong negative $\mathrm{Eu} / \mathrm{Eu}^{*}$ anomaly indicate the derivation of the Spitisiliciclastic sediments from a more felsic dominant source. Multi-elemental spider diagrams of the Thango clastic sediments and the Proterozoic and Paleozoic granitites from the Himalaya suggest that Tethyan sediments may have been derived from these granitoid belts. Detrital mineralogy and CIA values postulate that the provenance was affected by low to moderate degree of weathering. The high CIA values related to humid, non-glacial period (early Ordovician) and the low CIA values related to cold glacial period (late Ordovician).

Singh et al. (2019b) for the first time recorded Ordovician trace fossils from the Lesser Himalaya in the NigaliDhar Syncline, Himachal Pradesh. An angular unconformity separates Ordovician trace fossil bearing horizon with the underlying Lower Cambrian Shale Member of the KotiDhaman Formation (Tal Group).

\section{Silurian}

Myrow et al. (2018) reported a lower Silurian ozarkodinid fauna within the upper member of the Takche Formation that included Ozarkodina sp. cf. hassi, Oulodus sp., Panderodusuni costatus, and Distamodus sp., the latter is a lower Silurian index fossil, thus confirming a Llandovery, age for the uppermost Takche Formation. They provided a high-resolution $\sim 13 \mathrm{C}$ curvepossibly indicating latest Ordovician to earliest Silurian sea to a transition into a major icehouse condition. The curve shows a long-term positive excursion that is capped by a conspicuous positive spike, recorded within a thin calcareous algae-rich shale unit. Directly overlying strata shows an abrupt negative shift $(>1.5 \%)$ and then further negative drift of $\sim 1.3 \%$. When correlated to other sections globally, it indicated that the pattern represented the Paroveja (= BC-14, Elkhorn) positive excursion, the last major excursion prior to the KatianHirnantian boundary interval. They further suggested that the Takche Formation also recorded preHirnantian warming interval and an Hirnantian global cooling (Boda event).

\section{Carboniferous}

Singh et al. (2017d) described an ichnofossils assemblage comprising Asteriacites stelliformis, $A$. quinquefolius, Biformites insolitus, Helminthoidichnites? isp., Lingulichnus isp., Lockeia siliquaria, Palaeophycus tubularis, Planolites isp., Protovirgularia isp. A, Protovirgularia isp., B, 
Protovirgularia isp. C, Psammichnites isp., Rusophycus isp., and Treptichnus isp. from the Po Formation (Visean-Serpukhovian) exposed at the base of the Ganmachidam Hill near Chichong village, Spiti Valley. Sedimentary structures such as hummocky cross-stratification, low-angle planar and trough cross beds, and shallow, slightly asymmetrical gutter casts combined with the trace fossil assemblage indicated upper shoreface to lower shoreface of an open shelf environment of deposition.

The geochemical studies carried out by Ganai et al. (2016) and Ganai and Rashid (2019) suggested that varying Chemical Index of Alteration values (CIA) and $-4 \mathrm{Si} \%$ values corresponding to Lipak, Po and Ganmachidam formations of Spiti might have resulted due to varying weathering conditions in the provenance, i.e. warmer Devonian (more weathering), gradually becomes cooler during middle Carboniferous and finally leading to ice age during the PermoCarboniferous interval. Based on high $\mathrm{SiO}_{2}, \mathrm{Al}_{2} \mathrm{O}_{3}$ and relatively low $\mathrm{MgO}$ values coupled with immobile elemental ratios $\left(\mathrm{SiO}_{2} / \mathrm{Al}_{2} \mathrm{O}_{3}, \mathrm{Al}_{2} \mathrm{O}_{3} / \mathrm{TiO}_{2}\right)$ and LREE enriched and almost flat HREE patterns, Th/Sc, La/ $\mathrm{Sc}, \mathrm{Cr} / \mathrm{Th}, \mathrm{La} / \mathrm{Th}$, ratios and strong negative $\mathrm{Eu} / \mathrm{Eu}^{*}$ suggest derivation of sediments from the Proterozoic and Palaeozoic granitoids of the Himalaya (Rashid and Ganai, 2018). Geochemical palaeo-redox parameters such as $\mathrm{Ni} / \mathrm{Co}$ (4.0-7.2), $\mathrm{V} / \mathrm{Cr}$ (1.7-2.8), $\mathrm{V} /(\mathrm{V}+\mathrm{Ni})(0.6-0.9), \mathrm{V} / \mathrm{Sc}(7.2-29.1)$ and negative to subtle positive Ce anomalies indicate that DevonianCarboniferous black shales of the Lipak Formation represent an event of anoxia, which can be correlated with global events such as Hengenberg Events or the Lower Alum Shale Event in Germany. The phosphatic nodules occurring in these black shales show enriched $\mathrm{Y}$, Sr and REE abundances with high $\mathrm{P}_{2} \mathrm{O}_{5}$ contents and MREE enrichments, with a "hat-shaped" pattern and subtle positive Ce-anomalies. The hat-shaped patterns are linked to the formation of authigenic apatite caused by microbial decomposition of organic matter (Ganai and Rashid, 2019).

The ${ }^{13} \mathrm{C}$ values of the Lipak carbonates range from -8 to $+2.6 \%$ and $\delta^{18} \mathrm{O}$ from $-10-14.5 \%$, the large shift in values may represent facies change associated with the regression (Ganai et al., 2016).

Cleal et al. (2016) reported rich fossil flora of Serpukhovian age from the Fenestella Shales of
Manigam (Anantnag Kashmir). This assemblage of the northern margins of Gondwana, on the shores of the Palaeo-Tethys, is dominated by remains of an eligulate, mainly monopodial lycopsid with persistent leaves. The stems show considerable morphological variation that having been assigned to different fossilspecies and genera. Partially the morphological variation could have been due to variations in growth rate of the individual plants, which in turn may reflect stressed growing conditions in a wetland. The systematic position of Spondylodendron however, remains uncertain due to the lack of reproductive structures, though it may have affinity with the Sublepidodendraceae.

Agnihotri et al. (2018) using a single zircon (U$\mathrm{Pb}$ method) assigned $329 \pm 16 \mathrm{Ma}$ age (late Viséan to early Serpukhovian) for the Fenestella Shales, which coincides with the earlier observations based on faunal assemblage. The palynoflora of the Fenestella Shale was compared by these authors to the Carboniferous-Permian of Pakistan, Yemen, South America, South Africa, Antarctica, Australia and India. Mega-fossils of pteridophytes and gymnosperms monosaccate and bisaccate pollen grains and the trilete spores together with abundant Fenestella specimens indicate a marine coastal environment. Diverse micro- and megafloral assemblages of the Fenestella Shales in the Banihal area of Kashmir region suggest warm, temperate climatic conditions.

\section{Permian}

Ghosh et al. (2016) documented sedimentological and high-resolution trace element concentrations and carbon, oxygen, lead isotope data across the P-Tr boundary in Atargu and Guling sections in Spiti. Based on framboidal pyrites, fossils and laminated lithology of the Late Permian shales of the Gungri Formations deeper anoxic depositional environment was interpreted. $\delta^{13} \mathrm{C}$ org excursions of $2.4 \%$ and $3.1 \%$ in Atargu and Guling sections, respectively, signify the P-Tr transition across a clayey, partly gypsiferous ferruginous layer. Sedimentological similarities of this layer to other Neo-Tethyan sections from Transcaucasia and Iran indicate subaqueous oxidation of shallow marine sediments on a regional scale. Light Rare Earth Element-enriched Late Permian Gungri Shales with conspicuous Ce-Eu anomalies point to the adjacent Panjal Trap basalts (ca. $289 \mathrm{Ma}$ ) of 
Kashmir as source. Continental crustal $\mathrm{Nb}-\mathrm{Ta}$ and $\mathrm{Zr}$-Hf anomalies appear at the P-Tr boundary sediments, and extend to the overlying Early Triassic carbonates. Original $\mathrm{Pb}$ isotope ratios, along with an increasing $\mathrm{Pb}$ abundance closer to the P-Tr boundary, distinguish the volcanic source of the Late Permian shales from the continental crustal siliciclastic signature of the Early Triassic carbonates. The $\delta^{13} \mathrm{C}$ org, trace element and $\mathrm{Pb}$ isotope record from Spiti indicate catastrophic changes in sediment sources and facies, with effects on carbon cycle, which are consistent with an abrupt episode of marine regression and erosion also observed elsewhere along northern Gondwanaland. Simultaneous eruption of Siberian volcanics and bolide impacts in the Parana basin of Brazil and elsewhere implied impact-triggered volcanism that affected sea level, climate, marine anoxia and tectonic stability that connected the P-Tr crisis across global terrestrial and marine realms.

Jasper et al. (2016) recorded fragments of tracheids that show homogenized cell walls, a characteristic feature of charcoal in the Late Permian Zewan Formation of the Guryul ravine. This feature is regarded an evidence of palaeo-wildfire, which permits reconstructing environment during the Late Permian Zewan Formation.

Brosse et al. (2017) studied the conodont biochronology and isotopic records of the fifteen lowermost stratigraphical metres (Member E) of the Khunamuh Formation at the Guryul Ravine, which includes both the Permian-Triassic and the Griesbachian-Dienerian (Induan) boundaries. The FAD of Hindeodusparvus occurs in the middle of sub-member $\mathrm{E}_{2}$ bed (GUR09). They established 10 conodont Unitary Association zones. The $\mathrm{UAZ}_{1-2}$, of Late Permian, identified only in South China, $\mathrm{UAZ}_{3-10}$ are present both in China and the Guryul Ravine. The Griesbachian-Dienerian boundary is located within the interval of separation between $\mathrm{UAZ}_{7}$ and $\mathrm{UAZ}_{8}$. At the Guryul Ravine, the boundary is precisely constrained between beds GUR310 and GUR311 and corresponds to the replacement of Neogondolella to Sweetospathodus and Neospathodus conodonts. Brosse et al. (2017) also observed a conspicuous $\delta^{13} \mathrm{C}$ positive excursion and regarded it to a significant event at least at the scale of the Tethyan realm that could be used as a secondary proxy for the Griesbachian-Dienerian boundary. This global perturbation of the carbon isotope signal is linked to a climate change at the Griesbachian-Dienerian transition, from a cool and dry to a hot and humid climate. This transition could be the trigger of the migration of neogondolellids towards the high latitude, and of the radiation of neospathodids during the Dienerian.

Petrographic and, major and trace element geochemistry and rare earth elements studies of the late Permian and early Triassic sediments by Pillai et al. (2017) in the Guryul Ravine revealed a visible change in the lithostratigraphy from argillaceous carbonaceous mudstone in the $\mathrm{C}$ Member of the Zewan Formation, to fine grained argillaceous siltstone with quartz in the D Member, (4 m below the Late Permian Event Horizon. The XRD analysis indicates more terrigenous input below the PTB, which is also supported by the dominance of quartz whereas the dominant clay mineral illiteis followed by chlorite. The $\mathrm{K}_{2} \mathrm{O}+\mathrm{Na}_{2} \mathrm{O}$ vs $\mathrm{SiO}_{2}$ plot indicates that the sediments at the $\mathrm{PTB}$ were derived from andesite type of rocks $\left(\mathrm{SiO}_{2} 52-63 \%\right)$ of intermediate composition. Major oxides $\mathrm{SiO}_{2}, \mathrm{CaO}, \mathrm{Na}_{2} \mathrm{O}$ and $\mathrm{MnO}$ are most abundant in the D Member, whereas the E Member is enriched in the $\mathrm{Co}, \mathrm{Ni}, \mathrm{Cu}, \mathrm{V}$ and $\mathrm{Zn}$ signifying reducing conditions. Dominance of incompatible elements such as $\mathrm{Ti}, \mathrm{K}, \mathrm{Rb}$, and $\mathrm{Sr}$ in finer shale fraction shows increased reworking of sediments. Moderate weathering is observed at PTB, whereas below the LPEH, physical weathering is more pronounced. Y/ $\mathrm{HO}$ ratio varies from 24-51 indicating that REEs are derived from shale source. The $\mathrm{C}_{\mathrm{org}}: \mathrm{P}$ is $<10: 1$ in the late Permian whereas it is $>10: 1$ in the early Triassic Period suggesting that the conditions transformed from oxidizing to reducing (maximum values noticed in sample no. 5 (80:1)) indicating sub-oxic to anoxic conditions, which may be one of the causes of oceanic redox at PTB.

Study by Huang et al. (2019) revealed two pronounced stages of oceanic oxygen deficiency, in the latest Permian Hindeodus praeparvus-Clarkina meishanensis Zone and the earliest Triassic Isarcicella staeschei Zone. Updated marine invertebrate fossil records show three sharp species richness declines at the Guryul Ravine. The first decline occurred within the uppermost Permian storm beds and is interpreted to represent a facies control in which a storm-agitated environment was 
inhospitable for benthos. The latter two biotic declines coincided with two marine anoxic events, as documented by pyrite framboid distributions. The same two anoxic events are also recognized from PTB beds in the adjacent, relatively shallower Barus Spur section in Kashmir, in which newly obtained faunal data helped to constrain placement of the PTB. These authors reported a two-stage pattern of oceanic anoxia during the Permian-Triassic transition. They proposed that the two anoxic events at the Guryul Ravine correlate precisely with anoxic events in the Meishan GSSP and some sections in South China suggesting that this event might have been characteristic of the Permian-Triassic transition in some specific geological settings. The close relationship between oxygen depletion and species richness decline suggests that the former was an important contributor to the latter.

Kumar et al. (2017) discussed geochemistry of the Permian-Triassic sequences of the Guryul Ravine section, Jammu and Kashmir, India and its implications for oceanic redox conditions.

The studies on sandstones and black shales of the Mesozoic successions from the Spiti region, Tethys Himalaya, have yielded interesting results. The wide range of CIA values (i.e. 56-86) shown by these rock types indicate low to intense chemical weathering in the source area, which in turn implies variable climatic conditions that may have prevailed in the source region. The Spiti sedimentary samples show dramatic variation in the REE concentrations with prominent Ce positive and negative anomalies, which signifies the role of sea water dynamics (particularly changing redox conditions) during the deposition of these sediments. The concentration and the ratios of redoxsensitive elements $(\mathrm{V} / \mathrm{V}+\mathrm{Ni}$, and $\mathrm{V} / \mathrm{Sc})$ of the Mesozoic Spiti black shales represent anoxic conditions for their deposition. This inference is in conformity with the observed negative $\mathrm{Ce}$ anomalies in the black shales. The average Corg content for black shales is 0.745 (wt. \%), with a range of 0.2 to 2.13 (wt. \%), the lowest value recorded at Early Triassic or at the $\mathrm{P} / \mathrm{T}$ boundary and at Triassic/Jurassic boundary. Thus, the $\mathrm{C}_{\text {org }}$ content noticeably fluctuates from the Triassic to the Jurassic periods at different stratigraphic levels. This observation points that there was a decrease in $\mathrm{C}_{\text {org }}$ content perhaps due to a crash in productivity at theses boundaries, which in turn may have become one of the prime reasons for mass extinction at these boundaries. Carbon isotopic studies carried out on Mesozoic Spiti black shales show decrease in $\delta^{13} \mathrm{C}$ values or negative values (-22 to $27 \%$ ), indicating an input of isotopically light carbon. Fluctuations of $\delta^{13} \mathrm{C}$ values recorded in the shales coincide with the Early Triassic period after which the values return to relatively elevated values (from 27 to -24). These changes appear to be related with glacial intervals at terminal Permian periods and Early Triassic period (may be related with the PermianTriassic boundary).

\section{Mesozoic}

The Jurassic-Cretaceous marine sediments represented by the Tagling (Early Jurassic), Spiti, Guimal (Early Cretaceous), and Chikkim (Late Cretaceous) formations crop out in the Spiti Valley. The Spiti and Giumal formations are rich in ammonoids referable to Stage/Substage/Zone. Based on planktonic foraminifera five planktonic foraminiferal assemblages in the Chikkim Formation could be identified. The litho-biostratigraphic evaluation of the Jurassic-Cretaceous succession in the Spiti Valley reveals the presence of the T-OAE of late Early Toarcian in the youngest few meters of the Tagling Formation, Late Valanginian Weissert OAE, latest Hauterivian Faraoni OAE and Early Aptian OAE1a in the Giumal Formation, and probable an Early Albian OAE 1b, Late Albian OAE 1c and 1d, latest Cenomanian OAE 2 and Coniacian/Santonian OAE 3 in the Chikkim Formation (Pandey and Pathak, 2016).

\section{Jurassic}

Pandey and Pathak (2016) reported the presence ofthe T-Oceanic Anoxic Event of late Early Toarcian in the youngest few meters of the Tagling Formation.

Krishna (2017) published an interesting book on the Indian Mesozoic geological evolution in perspective of sequence stratigraphy. It is mainly based on ammonoid based high resolution scales in the Triassic and Jurassic period. In this book the Indian Late Precambrian - Neogene record is organized into five mega-sequences.

\section{Cretaceous}

The existing contribution to the understanding of the Early Cretaceous ammonoid record in India was carried out by Pandey et al. (2015) who suggested 
that the ammonoid bearing Early Cretaceous succession in the Spiti Himalaya, the Giumal Formation is ideal to carry out ammonoid based biostratigraphic studies. They opined that the record of the ammonoid genera Odontodiscoceras and Berriasella from the basal sandstone bed and Colombiceras, Deshayesites, Cleoniceras and Australiceras from the upper most sandstone beds, the age of the Giumal Formation ranges from Berriasian to Early Aptian.

Pandey and Pathak (2017) recorded new species of the ammonoid genus Olcostephanus Neumayr from the Lower Cretaceous Giumal Formation exposed near Gete village in the Spiti Valley. Itis one of the most significant genera for intrabasinal to intercontinental biochronostrati-graphic correlation in view of its episodic global expansion during the Valanginian. This first report included Olcostephanus (Olcostephanus) sakalavensis (Besairie), Olcostephanus (Olcostephanus) cf. salinarius, Olcostephanus (Olcostephanus) cf. fascigerus and Olcostephanus (Olcostephanus) sp. indet., from the Indian Cretaceous. Based on close resemblance with the well-known biostratigraphically precised Mediterranean and South American Olcostephanus species, the Indian taxa have been placed by these authors in the Neocomites platycostatus Subzone of the Karakaschicerasino stranzewi Zone to the Saynoceras verrucosum Subzone of the Saynoceras verrucosum Zone interval of the Standard Tethyan Scheme. Pandey and Pathak (2017) also proposed a possible correlation with Olcostephanus bearing stratigraphic horizons of South Africa, Madagascar and Pakistan. The findings confirmed a significant eustatic rise close to

hydrocarbon. The data are also supported by the FTIR and NMR studies.

\section{References}

Agnihotri D, PanditaS K, Tewari R, Linnemann U, Pillai S S K, Joshi A, Gautam S, Kumar K (2018) Palynology and detrital zircon geochronology of the Carboniferous Fenestella Shale Formation of the Tethyan realm in Kashmir Himalaya: Implications for global correlation and floristic evolution Journal Asian Earth Sciences 157 348-359

Brosse M, Baud A, Bhat G M, Bucher H, Leu M, Vennemann T the lower/upper Valanginian boundary.

Earlier, the Giumal Formation was assigned a vague Hauterivian - Albian age. Discovery of Odontodiscoceras and Berriasella at the lowest level and Colombiceras, Deshayesites and Australiceras in the topmost sandstone bed enabled precise dating of the Giumal Formation as BerriasianEarly Aptian (Pandey and Pathak, 2016, 2017; Pandey et al., 2018a, b). Discovery of this new faunal element enables demarcation of Berriasian, Valanginian, Hauterivian - Berremian and Aptian stages in the Giumal Formation.

Pandey et al. (2018a) erected a new neocomitin ammonite genus Geticeras from the Giumal Formation, named after Gete village. This discovery enabled the differentiation of Lower and Upper Valaginian substages within Valaginian.

The Chikkim Formation has been assigned a post-Aptian age (Pandey and Pathak, 2016, 2017; Pandey et al. 2018b). 20 samples of black carbonaceous shales in the Spiti and Chikkim formations of the Spiti valley of the Tethys Himalaya (Pandey et al. 2018b) were subjected to maceral analysis, Rock-Eval Pyrolysis. Six samples were analysed for Fourier Transform Infra-red Spectroscopy (FTIR) and nuclear magnetic resonance (NMR) analyses. The study revealed the presence of mainly kerogen-III type of organic matter, some of the shale samples showed total organic carbon (TOC) to the tune of $3.19 \%$. The results indicate the incidence of methane occurring as free and fixed hydrocarbon in these samples. A few levels were found rich in

and Goudemand G (2017) Conodont-based Griesbachianbiochronology of the Guryul Ravine section (Induan, Early Triassic, Kashmir, India) Geobios https:// doi.org/10.1016/j.geobios.2017.10.001

Craig J, Hakhoo N, Bhat G M, Hafiz M, Khan M R, Misra R, Pandita S K, Raina B K, Thurow J, Thusu B, Ahmed W and Khullar S (2018) Petroleum systems and hydrocarbon potential of the North-West Himalaya of India and Pakistan Earth-Science Reviews 187 109-185

Chaubey R S, Vinn O, Singh Birendra P, Bhargava O N, Prasad S K and Kishore N (2019) Warm water dasacladayence algae 
from the Ordovician-Silurian of Parahio Valley, Spiti, India Estonian Journal of Earth Sciences 68 45-53

Chaubey R S, Singh Birendra P, Mikuláš R, Bhargava O N, Kishore N and Prasad S K (2018) Integrated Ichnological and sedimentological analysis of the Cambrian Kunzam La (Parahio) Formation, Shian Section, Pin Valley, Spiti, Northwest Himalaya International Journal of Stratigraphy and Geological Correlation 26 709-721

Cleal C J, Bhat G M, Singh K J, Dar A M, Saxena A and Chandra S (2016) Spondylodendronpranabii-the dominant lycopsid of the late Mississippian vegetation of the Kashmir Himalaya Alcheringa 40 443-455

Ganai J A, Rashid S A and Romshoo S A (2018) Evaluation of terrigenous input, diagenetic alteration and depositional conditions of Lower Carboniferous carbonates of Tethys Himalaya, India Solid Earth Sciences 3 33-49

Ganai J A and Rashid S A (2019) Anoxia and fluctuating climate recorded from the Devonian-Carboniferous black shales, Tethys Himalaya, India: A multi-proxy approach International Journal Earth Sciences 108 863-883

Ganai J A, Rashid S A and Masroor A M (2016) Petrography and Geochemical studies of Upper Paleozoic sandstones from the Tethys Himalaya, Spiti Valley, Himachal Pradesh Journal Applied Geochem 18 3-14

Ghosh N, Basu A R, Bhargava O N, Shukla U K, Ghatak A, Garzione C N and Ahluwalia A D (2016) Catastrophic environmental transition at the Permian-Triassic NeoTethyan margin of Gondwanaland: Geochemical, isotopic and sedimentological evidence in the Spiti Valley, India Gondwana Research 34 324-345

Huang Y, Chena Z-Q, Algeo T J, Zhao L, Baud A, Bhat G M, Zhang L and Guo Z (2019) Two-stage marine anoxia and biotic response during the Permian-Triassic transition in Kashmir, northern India: pyrite framboid evidence Global Planet Change 172 124-139

Hughes N C, Myrow P M, Peng S and Banerjee D M (2018) The Parahio Formation of the Tethys Himalaya: The type section, thickness, lithostratography and biostratigraphy of the best characterized Cambrian succession in Indian sub-continent Journal Paleontological Society of India 63 $1-18$

Jasper A, Uhl D, Agnihotri D, Tewari R, Pandita S K, Wanderley J, Benicio F, Etiene F E, Augusto A, Da Rosa S, Bhat G D and Pillai S K (2016) Evidence of wildfires in the Late Permian (Changsinghian) Zewan Formation of Kashmir, India Current Science 110 419-423

Krishna J (2017) The Indian Mesozoic Chronicle. Springer 1459
Kaur R, Singh Birendra P, Bhargava O N, Singla G and Stopden S (2019) Cambrian trilobite fauna of the Haydenaspisparvatya level (Series 2, Stage 4): Its stratigraphic position with respect to the Oryctocephalus-indicus Biozone (Miaolingian Series, Wuliuan Stage) in the Spiti Himalaya, India Comptes Rendus Palevol 18 298-305

Kumar K, Tewari R, Agnihotri D, Sharma A, Pandita S K, Suresh S K, Pillai S K, Singh V and Bhat G D (2017) Geochemistry of the Permian-Triassic sequences of the Guryul Ravine section, Jammu and Kashmir, India: Implications for oceanic redox conditions Geo Res $J 13$ 114-125

Myrow P M, Fike A D, Malmskog B, Leslie S, Zhang T, Singh B P, Chaubey R S and Prasad S K (2018) Ordovician-Silurian boundary strata of the Indian Himalaya: Record of the latest Ordovician Boda Event Geological Society America Bulletin doi.org/10.1130/B31860.1

Pandey S and Parcha S K (2018) Calcareous algae from the Ordovician succession (Thango Formation) of the Spiti Basin, Tethys Himalaya, India Acta Palaeobotanica doi: 10.2478/acpa-2018-0009

Pandey B and Pathak D B (2016) The possibility of the Oceanic Anoxic Events (OAEs) study in the Indian marine JurassicCretaceous outcrops Journal Geological Society of India 87 261-267

Pandey B and Pathak D B (2017) Biostratigraphic implication of Olcostephanus Neumayr, 1875 (Ammonoidea) from the Lower Cretaceous Giumal Formation, Spiti Valley, Tethys Himalaya, India Cretaceous Research 70 244-251

Pandey B, Pathak D B and Jaitly A K (2018a) A new ammonite gen. nov. from the Lower Valanginian (Lower Geticeras Cretaceous) of the Spiti Valley, Tethys Himalaya, India Himalayan Geology 39 115-120

Pandey B, Pathak D B, Mathur N, Jaitly A K, Singh A K and Singh P K (2018b) A Preliminary Evaluation on the Prospects of Hydrocarbon Potential in the Carbonaceous Shales of Spiti and Chikkim Formations, Tethys Himalaya, India Journal Geological Society of India 92 427-434

Parcha S K and Pandey S (2016) Trace fossils and microbially induced sedimentary structures from the early Cambrian successions of the Chandratal area, Spiti Basin, Tethys Himalaya Journal Paleontological Society of India 61 9-18

Rashid S A and Ganai J A (2018) Depositional environments, provenance and paleoclimatic implications of Ordovician siliciclastic rocks of the Thango Formation, Spiti Valley, Tethys Himalaya, northern India Journal Asian Earth Science 157 371-386

Singh Birendra P, Virmani N, Bhargava O N, Negi R S, Gill A and Kishore N (2016a) Trilobite fauna of basal Cambrian Series 
3 (Stage 5) from the Parahio Valley (Spiti), Northwest Himalaya, India and its biostratigraphic signiûcance Annales de Paléontologie 102 59-67

Singh Birendra P, Virmani N, Bhargava O N and Gill A (2016b) Revision of diagnostic features of the trilobite genus Bhargavia (Ellipsocephaliodea) from the Parahio valley (Spiti), Northwest Himalaya, India Journal Paleontological Society of India 61 9-14

Singh Birendra P, Chaubey R S, Bhargava O N, Prasad S K and Negi R S (2017a) The Cambrian trilobite fauna from the Shian (Saybang) section, Pin Valley (Spiti) and its biostratigraphic signiûcance Palaeoworld 26 25-36

Singh Birendra P, Bhargava O N, Negi R S, Zhao Y, Yin L and Sharma C A (2017b) Additional trilobite fauna from the basal part of the Cambrian Series 3, Stage 5, Kunzam La (=Parahio) Formation, Parahio Valley, Spiti (Northwest Himalaya), India and its biostratigraphic significance Annales de Paleontologie 103 271-281

Singh Birendra P, Bhargava O N, Sharma C A, Chaubey R S, Prasad S K, Negi R S and Kishore N (2017c) Treptichnus ichnogenus from the Cambrian of India and Bhutan: Its relevance to the Precambrian-Cambrian boundary Journal Paleontological Society of India 62 39-51

Singh Birendra P, Bhargava O N, Mikuláš R, Prasad S K, Singla G and Kaur R (2017d) Asteriacites and other trace fossils from the Po Formation (Visean-Serpukhovian), Ganmachidam Hill, Spiti Valley (Himalaya) and its paleoenvironmental significance Geologica Carapathica 68 464-478
Singh Birendra P, Bhargava O N, Mikuláš R, Scott M, Kaur R, Singla G, Kishore N, Kumar N, Kumar R and Moudgil S (2019a) Integrated sedimentological, ichnological and sequence stratigraphical studies of the KotiDhaman Formation (Tal Group), NigaliDhar Syncline, Lesser Himalaya, India: paleoenvironmental, paleoecological, paleogeographic significance Ichnos doi: 10.1080/ 10420940.2019.1584560

Singh Birendra P, Bhargava O N, Mikuláš R, Prasad S K, Morrison S, Chaubey R S and Kishore N (2019b) Discovery of Ordovician trace fossils from the Lesser Himalaya, India: its stratigraphic, tectonic and palaeogeographic implications Journal Palaeontological Society of India 64 283-303

Sinha H N and Verniers J (2016) Discovery of the chitinozoans Belonechitinacapitata from the Shiala Formation of northeastern Garhwal-Kumaun Tethys Himalaya, Pithoragarh District, Uttrakhand, India Geoscience Frontiers 7 859864

Srikantia S V and Bhargava O N (2018) Stratigraphic nomenclature of early Palaeozoics of the Spiti Himalaya: Cobweb Cleared Journal Paleontological Society of India 63 233-241

Swami N K, Ernst A, Tripathi S C, Barman P, Bharti S K and Rana Y P (2019) A new cryptostome bryozoan Ptilotrypa from the Upper Ordovician Yong Limestone Formation: Tethyan sequence of Kumaun Higher Himalaya, India Journal Paleontology doi: 10.1017/jpa.2018.94

Yin L, Singh Birendra P, Bhargava O N, Zhao Y, Negi R S, Meng F W and Sharma C A (2017) Palynomorphs from the Cambrian Series 3, Parahio valley (Spiti), Northwest Himalaya Palaeoworld 27 30-41. 